\title{
MENINGKATKAN KEMAMPUAN KONEKSI MATEMATIS SISWA SMP DENGAN PENDEKATAN KONTEKSTUAL MELALUI PEMBELAJARAN KOOPERATIF TIPE TEAM ASSISTED INDIVIDUALIZATION
}

\author{
Shabrina Khairunisa ${ }^{1}$, Ika Wahyu Anita ${ }^{2}$, Asep Ikin Sugandi ${ }^{3}$ \\ 1,2,3 IKIP Siliwangi Bandung \\ ${ }^{1}$ shabrina9111.kh@gmail.com, 2ikawahyu@ikipsiliwangi.ac.id, ${ }^{3}$ sugandi@ikipsiliwangi.ac.id
}

\begin{abstract}
This research examines the learning of mathematics-learning cooperatives the type of Team Assisted Individualization with contextual approach and it is relation with improved mathematical connection quality of high school (Junior High School) Private in the city of Bandung. The purpose of this research was: know how to increasiing learner mathematical connection quality who follow the method of contextual approach Through Cooperative Learning the Type of TAI compared with students who follow the teaching of mathematics with the conventional models, implementation approach contextual approach in class and the difficulties faced students of middle school in solving about the connection mathematics. The study instrument apply was a black-and-white exam mathematical connection quality. The results obtained in the form of the pretest and posttest scores then processed with statistical methods test the difference of two averages. The output indicate that improvement of connection quality of middle school student who follow the method of contextual approach Through Cooperative Learning the Type of TAI is more increased compared with students who follow the teaching of mathematics with the conventional models. Implementation contextual approach can improve the ability of connection mathematics students middle school, the difficulties faced students middle school in solving about the connection mathematics is indicator using math in the part of another study or in daily life.
\end{abstract}

Keywords: Team Assisted Individualization, contextual approach, Mathematical Connection.

\begin{abstract}
Abstrak
Penelitian ini mengkaji peningkatan keterampilan koneksi matematis pelajar SMP dengan pendekatan kontekstual melalui pembelajaran matematika kooperatif tipe TAI. Metode riset yang dipakai yaitu metode eksperimen melalui pola riset berbentuk pola grup kontrol pretespostes. Subjek pada riset ini adalah pelajar kelas VII di SMP swasta di kota Bandung. Tujuan dari riset ini adalah mengetahui bagaimana pencapaian dan peningkatan keterampilan koneksi matematis pelajar SMP dengan pendekatan kontekstual melalui pembelajaran kooperatif tipe TAI dikomparasikan dengan pelajar yang mengikuti pembelajaran matematika dengan pembelajaran biasa. Instrumen riset yang dipakai yaitu ujian tertulis keterampilan koneksi matematis. Hasil riset yang diperoleh berupa skor pretes dan postes lalu diolah dengan metode statistik uji-t. Hasil riset memperlihatkan bahwa pencapaian dan peningkatan keterampilanan koneksi matematis pelajar SMP dengan pendekatan kontekstual melalui pembelajaran kooperatif tipe TAI lebih meningkat dibandingkan dengan pelajar yang mengikuti pembelajaran matematika dengan pembelajaran biasa.
\end{abstract}

Kata Kunci: Team Assisted Individualization, pendekatan kontekstual, koneksi matematis

How to cite: Khairunisa, S., Anita, I. W., \& Sugandi, A. I. (2018). Meningkatkan Kemampuan Koneksi Matematis Siswa SMP dengan Pendekatan Kontekstual melalui Pembelajaran Kooperatif Tipe Team Assisted Individualization. JPMI - Jurnal Pembelajaran Matematika Inovatif, 1 (6), 1129-1134. 


\section{PENDAHULUAN}

Matematika adalah salah satu cabang pengetahuan yang mempunyai karakter menyeluruh dan menjadi dasar perkembangan teknologi modern. Di samping itu matematika memiliki peranan vital di segala bidang ilmu dan dalam mengembangkan pola pikir setiap orang. Hal ini terlihat dari pesatnya pertumbuhan IPTEK dan komunikasi yang didasari oleh pertumbuhan matematika diantaranya dalam bidang teori bilangan, aljabar, analisis, teori peluang dan matematika diskrit. Maka dapat diasumsikan penguasaan pemahaman matematika sangat diperlukan sejak dini untuk mewujudkan teknologi pada waktu yang akan datang(Frastica, 2013).

Menurut Sumarmo (Yuniawatika, 2011) agar mengerti dan memahami matematika, peserta didik harus mampu mengoneksikan antar gagasan matematika serta mengoneksikan antara matematika dengan cabang pengetahuan lainnya sehingga penguasaan dan pengertian siswa yang valid juga mendalam akan didapat. Siswa pada akhirnya memahami bahwa matematika bukanlah sekumpulan materi yang terpisah melainkan matematika erat kaitannya dan saling terhubung (connected) dengan cabang pengetahuan lain, bisa diartikan materi matematika saling berkaitan dengan materi sebelumnya. Anita (2014) menyatakan bahwa keterampilan mengoneksikan sebuah konsep matematis menjadi tahapan awal dan syarat utama agar siswa mampu menguasai dan memahami kemampuan lainnya dengan lebih tinggi.

Berdasarkan penjelasan tersebut maka bisa diartikan bahwa keterampilan koneksi matematika yaitu keterampilan dalam menghubungkan gagasan matematika ke dalam gagasan matematika itu sendiri dan kemampuan dalam menghubungkan gagasan matematika dengan cabang pengetahuan yang lain dalam keseharian kita. Linto, Elniati, \& Rizal (2012) mengatakan bahwa keterampilanan koneksi matematis menjadi syarat dan bagian penting dalam menguasai dan mengerti gagasan matematika agar bisa diterapkan pulan dalam keseharian kita. Selain itu ketika peserta didik telah sanggup menghubungkan materi matematika dengan materi yang lalu atau mengaitkan terhadap bidang studi lainnya maka belajar matematika menjadi lebih bermakna.

Tetapi kondisi di lapangan memperlihatkan bahwa keterampilan koneksi matematika cenderung di bawah rata-rata. Hal tersebut diperkuat dengan riset Ruspiani (Badjeber \& Fatimah, 2004) yang menyatakan bahwa pencapaian keterampilan koneksi matematika pelajar sekolah menengah belum cukup memenuhi yaitu kurang dari 60\%. Dengan hasil riset yang telah diperoleh tersebut bahwa kebanyakan siswa tidak dapat menghubungkan antar pembahasan yang sudah mereka terima dengan cara memanfaatkannya terhadap situasi nyata maka sangat diperlukan suatu pendekatan dalam proses pembelajaran. Berdasarkan uraian tersebut dibutuhkan usaha untuk menaikkan keterampilan koneksi matematis, usaha yang bisa ditempuh adalah melakukan pembelajaran dengan berbagai pendekatan. Pendekatan yang diterapkan di sekolah pada umumnya menggunakan pendidik sebagai sumber belajar.

Proses belajar melalui pendekatan konstektual menurut Hosnan (Sugandi, 2015) yaitu konsep pengajaran sehingga pendidik terbantu dalam mengaitkan antar pembahasan yang diperolehnya dalam kehidupan nyata siswa serta mendukung mereka membentuk koneksi antara wawasan yang mereka terima dengan pengaplikasiannya dalam kehidupan sehari-hari. Pendekatan yang dipakai yaitu Pendekatan Kontekstual karena pendekatan ini sangat menekankan siswa untuk menjadi pusat pembelajaran di dalam kelas dan pendidik terbantu untuk menghubungkan pembahasan yang disampaikan dalam keseharian siswa. Dalam Pendekatan Kontekstual siswa diharapkan agar mempunyai keterampilan koneksi dan fokus dalam proses belajar yang efektif. 
Oleh sebab itu seorang guru haruslah menjadi fasilitator bagi siswa untuk mempermudah siswa dalam pembelajaran. Selain dengan Pendekatan Kontekstual, peneliti juga mengombinasikan dengan Pembelajaran Kooperatif Tipe TAI yang menggabungkan pembelajaran individu dengan pembelajaran kelompok sehingga perserta didik yang belum berani dan belum percaya diri secara individu akan termotivasi dengan bantuan teman kelompoknya. Rumusan masalah serta maksud dari riset ini ialah untuk mengetahui dan menelaah: (1) Pencapaian keterampilan koneksi matematis siswa SMP yang memakai Pendekatan Kontekstual melalui Pembelajaran Kooperatif tipe TAI lebih baik daripada memakai pembelajaran biasa. (2) Peningkatan keterampilan koneksi matematis siswa SMP yang memakai Pendekatan Kontekstual melalui Pembelajaran Kooperatif tipe TAI lebih meningkat daripada memakai pembelajaran biasa.

\section{METODE}

Metode dalam riset tersebut yaitu metode eksperimen disertai cara membandingkan kelas kontrol dan kelas eksperimen. Pada kelas kontrol dan kelas eksperimen diberikan pretes dan postes dengan maksud untuk memperoleh data apakah terdapat perbedaan antara pembelajaran yang memakai Pendekatan Kontekstual melalui Pembelajaran Kooperatif tipe TAI dengan yang memakai pembelajaran biasa, maka desain riset yang dipakai yaitu desain kelompok kontrol pretes dan postes sehingga desain riset digambarkan sebagai berikut:
A $\quad \mathrm{O} \quad \mathrm{X} \quad \mathrm{O}$
$\mathrm{A} \mathrm{O} \quad \mathrm{O}$

Keterangan

A : Pengambilan sampel secara acak berdasarkan kelas

O: Soal pretes $=$ soal postes

X: Pembelajaran dengan Pendekatan Kontekstual melalui Pembelajaran Kooperatif tipe TAI

\section{HASIL DAN PEMBAHASAN}

\section{Hasil}

\section{Analisis Data Pretes Kemampuan Koneksi Matematis}

Tabel 1. Hasil Uji Dua Rata-rata Data Pretes Kemampuan Koneksi Matematis

\begin{tabular}{llccc}
\hline & & \multicolumn{2}{c}{ t-test for equality of means } \\
\cline { 2 - 4 } nilai & \multicolumn{1}{c}{$\boldsymbol{d}$} & $\boldsymbol{d f}$ & Sig. (2-tailed) \\
$\begin{array}{l}\text { Equal } \\
\text { variances } \\
\text { assumed }\end{array}$ & 0,115 & 55 & 0,909 \\
\hline & $\begin{array}{l}\text { Equal } \\
\text { variances not } \\
\text { assumed }\end{array}$ & 0,114 & 53,878 & 0,909 \\
\hline
\end{tabular}

Berdasarkan Tabel 1. hasil Uji-t keterampilan koneksi matematis dengan signifikansi 0,909 lebih besar dari 0,05 maka $\mathrm{H}_{0}$ diterima. Maka bisa diartikan bahwa tidak terdapat perbedaan rata-rata kemampuan awal koneksi matematis siswa kelas eksperimen dan kelas kontrol, sehingga penelitian beikutnya ialah memberikan perlakuan pada masing-masing kelas untuk memperoleh data postes sebagai bahan menjawab rumusan masalah pertama. 
1132 Khairunisa, Anita, \& Sugandi Meningkatkan Kemampuan Koneksi Matematis Siswa SMP...

\section{Analisis Data Postes Kemampuan Koneksi Matematis}

Tabel 2. Hasil Uji Dua Rata-rata Data Postes Kemampuan Koneksi Matematis

\begin{tabular}{llccc}
\hline & & \multicolumn{2}{c}{$\boldsymbol{t}$-test for equality of means } \\
\cline { 2 - 4 } nilai & $\boldsymbol{t}$ & $\boldsymbol{d f}$ & Sig. (2-tailed) \\
& $\begin{array}{l}\text { Equal } \\
\text { variances } \\
\text { assumed }\end{array}$ & 6,160 & 55 & 0,000 \\
\cline { 2 - 4 } & & & 0,000 \\
& $\begin{array}{l}\text { Equal } \\
\text { variances not } \\
\text { assumed }\end{array}$ & 6,153 & 54,138 & \\
\hline
\end{tabular}

Berdasarkan Tabel 2 hasil Uji-t keterampilan koneksi matematis dengan signifikansi 0,000. Nilai signifikansinya 0,000 karena $0,000<0,05$ maka $\mathrm{H}_{0}$ ditolak dan $\mathrm{H}_{1}$ diterima. Oleh karena itu bisa diartikan bahwa pencapaian keterampilan koneksi matematis yang pembelajarannya memakai Pendekatan Kontekstual melalui Pembelajaran Kooperatif tipe TAI lebih baik daripada yang memakai pembelajaran biasa.

\section{Pembahasan}

Riset di atas berorientasi kepada meninjau seberapa besar pencapaian keterampilan koneksi matematis setelah pembelajaran dilakukan dan untuk melihat pula seberapa besar pencapaian keterampilan koneksi antara kelas eksperimen dan kelas kontrol. Dari kedua kelas tersebut diberikan perlakuan yang berbeda, untuk kelas eksperimen menggunakan Pendekatan Kontekstual melalui Pembelajaran Kooperatif tipe TAI sedangkan untuk kelas kontrol memakai proses pengajaran biasa. Pembelajaran yang memakai Pendekatan Kontekstual pada saat di lapangan membuat proses belajar lebih berarti karena siswa dituntun agar menghubungkan materi-materi yang sudah diperoleh dengan konteks keseharian mereka. Kontekstual yaitu proses pengajaran yang menguatkan siswa dalam mengaplikasikan disiplin ilmu baik teori dan praktek akademis baik di dalam atau pun di luar institusi belajar dengan beragam latar belakang supaya dapat memecahkan problematika di kehidupan nyata, Yasin (Akbar, 2015).

Dengan memadukan Pendekatan Kontekstual dan Pembelajaran Kooperatif tipe TAI mampu menolong siswa untuk belajar lebih bermakna, menyenangkan dan dapat memperluas gagasan yang dimilikinya. Pembelajaran yang digunakan di kelas eksperimen mendidik siswa supaya menemukan penyelesaian permasalahan dalam LKS yang berisikan kemampuan koneksi yang mengaitkannya ke dalam situasi nyata. Sehingga memacu siswa supaya mampu mengaplikasikannya di kesehariannya. Model Pembelajaran Kooperatif tipe TAI pada saat diterapkan di lapangan mampu meningkatkan siswa dalam hal pengetahuan, keterampilan serta motivasi ketika belajar kelompok.

Ulya, Irawati, \& Maulana (2016) menyatakan bahwa pendekatan kontekstual cenderung unggul secara signifikan daripada pendekatan konvensional dan keterampilan koneksi matematika serta dukungan pembelajaran peserta didik memiliki hubungan yang positif dengan keeratan hubungan tergolong kuat, baik di kelas eksperimen maupun kelas kontrol. Dengan demikian bisa diartikan bahwa ketika keterampilan koneksi matematika tinggi maka dukungan belajar peserta didik pun tinggi Semuanya sejalan terhadap kemampuan dan model yang sama yang dilakukan peneliti sehingga menjadikan siswa memiliki wawasan luas serta dapat menghubungkan matematika terhadap keseharian siswa. Dari pernyataan tersebut peneliti menyimpulkan bahwa pencapaian dan peningkatan keterampilan koneksi dengan Pendekatan 
Kontekstual melalui Pembelajaran Kooperatif tipe TAI lebih meningkat daripada dengan pembelajaran biasa.

\section{KESIMPULAN}

Melihat hasil riset serta pengolahan data pada keseluruhan tahapan penelitian dengan mengacu pada rumusan masalah yang dikemukakan pada pendahuluan, maka dapat diambil kesimpulan: (1) Pencapaian keterampilan koneksi matematis siswa SMP yang memakai Pendekatan Kontekstual melalui Pembelajaran Kooperatif Tipe TAI lebih baik daripada dengan menggunakan pembelajaran biasa. (2) Peningkatan keterampilan koneksi matematis siswa SMP yang memakai Pendekatan Kontekstual melalui Pembelajaran Kooperatif Tipe TAI lebih meningkat daripada dengan memakai pembelajaran biasa. Pembelajaran yang menerapkan Pendekatan Kontekstual melalui Pembelajaran Kooperatif Tipe TAI menjadikan siswa memahami materi yang saling terkait dengan dunia nyata di keseharian mereka dan memberikan pengetahuan mendalam mengenai pembelajaran matematika, menjadikan siswa tidak pasif serta tidak takut untuk berbagi pemikirannya di dalam kelas. Kesimpulan tersebut memberikan saran sebagai berikut: (1) Hasil riset memperlihatkan jika proses belajar matematika yang memakai Pendekatan Kontekstual melalui Pembelajaran Kooperatif Tipe TAI memberikan pengaruh pada keterampilan koneksi matematika siswa, maka pembelajaran ini bisa direkomendasikan sebagai salah satu alternatif pembelajaran untuk menaikkan keterampilan koneksi matematis siswa. (2) Sebaiknya dilakukan penelitian lanjutan dengan bahan ajar lain untuk melihat secara nyata efektifitas pembelajaran matematika yang memakai Pendekatan Kontekstual melalui Pembelajaran Kooperatif Tipe TAI ini.

\section{DAFTAR PUSTAKA}

Akbar, R. F. (2015). and Learning untuk Pengembangan Pembelajaran PAI A . Pendahuluan Perubahan paradigma pembelajaran dari teacher center ke student center mendorong terjadinya perubahan gaya mengajar yang lebih menekankan kepada keaktifan peserta didik . Guru pada masa lalu. Jurnal Penelitian Pendidikan Islam, 10(2), 211-228.

Anita, I. W. (2014). Pengaruh Kecemasan Matematika ( Mathematics Anxiety ) Terhadap Kemampuan Koneksi Matematis Siswa SMP. Jurnal Ilmiah Program Studi Metematika STKIP Siliwangi Bandung, 3(1), 125-132.

Badjeber, R., \& Fatimah, S. (2004). PENINGKATAN KEMAMPUAN KONEKSI MATEMATIS SISWA SMP MELALUI PEMBELAJARAN INKURI MODEL ALBERTA. Jurnal Pengajaran MIPA, 20(1), 18-26.

Frastica, Z. R. (2013). Peningkatan Kemampuan Koneksi Matematis Melalui Pendekatan Open-Ended Pada Siswa SMP Ditinjau dari Perbedaasn Gender. Universitas Islam Negeri Sunan Kalijaga.

Linto, R. L., Elniati, S., \& Rizal, Y. (2012). Kemampuan koneksi matematis dan metode pembelajaran quantum teaching dengan peta pikiran. Jurnal Pendidikan Matematika, 1(1), 83-87. https://doi.org/10.13989/j.cnki.0517-6611.2015.10.011

Sugandi, A. I. (2015). Prossiding. In Penerapan Pendekatan Kontekstual Terhadap Kemampuan Komunikasi Matematis dan Kemandirian Belajar Siswa SMP (Vol. 3, pp. 45-53). 
1134 Khairunisa, Anita, \& Sugandi Meningkatkan Kemampuan Koneksi Matematis Siswa SMP...

Ulya, I. F., Irawati, R., \& Maulana. (2016). Peningkatan Kemampuan Koneksi Matematis Dan Motivasi Belajar Siswa Menggunakan Pendekatan Kontekstual. Jurnal Pena Ilmiah, 1(1), 121-130.

Yuniawatika. (2011). Penerapan Pembelajaran Matematika dengan Strategi React Untuk Meningkatkan Kemampuan Koneksi dan Representasi Matematik Siswa Sekolah Dasar. Edisi Khusus, (1), 105-119. 